\title{
Composition of the vaginal microbiota during pregnancy in women living in sub- Saharan Africa: a PRISMA-compliant review
}

Naomi C. A. Juliana ${ }^{1}$, Remco P. H. Peters ${ }^{2,3,4}$, Salwan Al-Nasiry ${ }^{5}$, Andries E. Budding ${ }^{6}$, Servaas A. Morré ${ }^{1,7}$ and Elena Ambrosino ${ }^{1 *}$

\begin{abstract}
Background: The vaginal microbiota (VMB) are the set of microorganisms residing in the human vagina. During pregnancy, their composition is Lactobacillus-dominant in most Caucasian women. Previous studies suggest that the VMB of women with African ancestry is more likely to be non-Lactobacillus dominant (dysbiotic) compared to other populations, and possibly relate to the high incidence of pregnancy complications, such as preterm birth. This work reviewed the literature on VMB composition in pregnant women from sub-Saharan Africa.

Methods: A search was conducted in PubMed and Embase databases following PRISMA guidelines. Observational and intervention studies analysing VMB communities from sub-Saharan African pregnant women using molecular techniques were included.

Results: Ten studies performed in seven sub-Saharan African countries were identified. They independently showed that Lactobacillus-dominant VMB (particularly L. iners or L. crispatus) or VMB containing Lactobacilli are the most prevalent, followed by a more diverse anaerobe-dominant VMB, in the studied populations. The majority of pregnant women with a sexually-transmitted infection had a Lactobacillus-dominant VMB, but with a significantly higher presence of anaerobic species.

Conclusion: In agreement with studies performed in other populations, Lactobacillus species are the most prevalent VMB species during pregnancy in sub-Saharan African women. The frequency of diverse anaerobedominant VMB is high in these populations. In Africa, studies on VMB in pregnancy are scant, heterogeneous in methodology, and knowledge remains limited. More insights on VMB composition and their possible sequalae among these populations is needed.
\end{abstract}

Keywords: Vaginal microbiota, Vaginal microbiome, Vaginal dysbiosis, Pregnancy, Sub-Saharan Africa, Africa

\footnotetext{
* Correspondence: e.ambrosino@maastrichtuniversity.nl

'Department of Genetics and Cell Biology, Faculty of Health, Medicine and Life Sciences, Research School GROW (School for Oncology \& Developmental Biology), Institute for Public Health Genomics, Maastricht University, Maastricht, Netherlands

Full list of author information is available at the end of the article
}

(C) The Author(s). 2021 Open Access This article is licensed under a Creative Commons Attribution 4.0 International License, which permits use, sharing, adaptation, distribution and reproduction in any medium or format, as long as you give appropriate credit to the original author(s) and the source, provide a link to the Creative Commons licence, and indicate if changes were made. The images or other third party material in this article are included in the article's Creative Commons licence, unless indicated otherwise in a credit line to the material. If material is not included in the article's Creative Commons licence and your intended use is not permitted by statutory regulation or exceeds the permitted use, you will need to obtain permission directly from the copyright holder. To view a copy of this licence, visit http://creativecommons.org/licenses/by/4.0/ The Creative Commons Public Domain Dedication waiver (http://creativecommons.org/publicdomain/zero/1.0/) applies to the data made available in this article, unless otherwise stated in a credit line to the data. 


\section{Background}

The number of studies on the microbial communities residing in the human vagina, the vaginal microbiota (VMB), and their role in female reproductive health has increased over the past two decades. Recent developments in molecular biology offer innovative opportunities for VMB profiling, but a full understanding of its role in reproductive health is still missing [1]. Usually, the VMB communities are characterized by the most dominant bacterial species, as it is the case for the Community State Types (CSTs) classification [2, 3]. Studies in North America and Europe consistently show that most women of reproductive age, irrespective of the pregnancy status, have a VMB dominated by one of four Lactobacillus species: Lactobacillus iners, Lactobacillus crispatus, Lactobacillus gasseri, or Lactobacillus jensenii $[2,3]$. Lactobacilli can control the vaginal $\mathrm{pH}$ levels by producing lactic acid, which is one of the mechanisms maintaining eubiosis and protecting the vaginal milieu from pathogens.

There is increasing evidence that VMB dominated by L. crispatus, L. gasseri, or L. jensenii relate to a healthy vaginal state, and that an overgrowth of (facultative) anaerobes, such as Gardnerella, Atopobium, and Prevotella species contributes to a dysbiotic vaginal state. A dysbiotic vaginal state is often defined as a prolonged deviation from a low-diversity, Lactobacilli-dominated VMB [4]. This vaginal state and its associated bacteria have been linked to the vaginal condition bacterial vaginosis (BV) [5]. While most Lactobacillus species are associated with a healthy vaginal state, low proinflammatory cytokine production, and desirable birth outcomes $[6,7]$, it remains unclear what type of vaginal state is associated with an L. iners-dominated VMB [8-10]. L. iners is generally considered a vaginal symbiont, but it can also be a potential opportunist pathogen [9]. Furthermore, $L$. crispatus has been shown to hinder colonization by anaerobe bacteria such as $G$. vaginalis, whereas $L$. iners co-exists with such aerobic microorganisms [11]. However, it is not yet clear whether harboring facultative anaerobic bacteria should always be categorized as an unhealthy vaginal microbiota state, as this microbial composition had also been observed in symptoms-free women [11].

Recent studies show that women from African countries or African ancestry more often have a VMB composition that contains BV-related bacteria compared to Caucasian women $[2,3,12-16]$. In these studies, the VMB composition was dominated by Gardnerella vaginalis, $A$. vaginae, and other anaerobic species instead of by Lactobacillus species [2, 3, 12-16]. Some of these studies observed that most women from sub-Saharan African or with sub-Saharan African ancestry that displayed a non-Lactobacillus-dominant VMB did not have any clinical symptoms associated with bacterial vaginosis. This suggests the possibility of a healthy nonLactobacilli-dominant VMB state [2, 12, 17, 18]. It is possible that ethnicity, among other factors, influences the VMB composition, through host-genetic factors.

Understanding the role of VMB in health and disease becomes complex when comparing women with different ethnic backgrounds [2, 14, 17, 19]. Besides ethnicity also, hormones influence the VMB. In early pregnancy, changes in hormone levels affect the VMB composition: Lactobacillus species are increased and G. vaginalis and other (facultative) anaerobic bacteria progressively decrease from the first to the third trimester [17, 19-22]. Following these changes, the VMB remains relatively stable (especially compared to the non-pregnancy state) along most of the pregnancy. During pregnancy changes commonly entail transitions between different Lactobacilli species $[15,21]$. However, even in pregnancy, the frequency of Lactobacillus-dominant VMB among women of African ancestry is lower compared to women of European ancestry. Furthermore, women of African ancestry are more likely to switch from Lactobacillus dominated VMB to a VMB commonly associated with vaginal dysbiosis [15]. Vaginal dysbiosis has been related to various adverse pregnancy outcomes, including preterm birth and higher susceptibility to sexually transmitted infections (STIs) [1, 18, 23-25].

An exhaustive understanding of what constitutes a healthy/normal VMB is lacking. Such knowledge, including appreciation of how VMB composition might impact pregnancy outcomes, is of great importance in areas where the overall burden of pregnancy complications and infections is high [26, 27]. Sub-Saharan Africa suffers a particularly high burden of these conditions: this region has an estimated preterm birth rate of $12 \%$ in 2014, accounting for $25 \%$ of all preterm births globally. Between 2010 and 2015, the estimated STI prevalence in pregnancy was up to $4.6 \%$ for Neisseria gonorrhoeae (NG), $6.5 \%$ for syphilis, $7.2 \%$ for C. trachomatis (CT), $25 \%$ for Trichomonas vaginalis (TV), and mother-tochild transmission of the human immunodeficiency virus (HIV) ranged between 5 and 30\% in sub-Saharan Africa $[1,18,23,28-31]$.

There is increasing research interest in understanding how the VMB composition might contribute to, and offer a predictive diagnostic potential for reproductive health outcomes. To date, most VMB pregnancy-related studies and reviews are based on data from NorthAmerican and European cohorts of women. Factors influencing the VMB, such as the host (including hostgenetics), behavioural (including sexual and cleaning practices), sociodemographic, nutritional, and environmental ones, are nonetheless different across geographical regions and cultures [14, 32, 33]. Comparing VMB 
composition across women of different populations and extrapolating data from one to explain health outcomes on others might not be an accurate approach $[8,34]$.

This review aims to compile available data from original research that characterized the VMB composition among pregnant women living in sub-Saharan Africa. Insights from this review are expected to offer background evidence to assist in designing future observational studies to investigate the VMB's role on pregnancy outcomes and STIs. These are also expected to assist the design of future VMB-related intervention studies that aim to decrease vaginal dysbiosis and its related health problems in sub-Saharan African countries.

\section{Methods}

Searches according to the Preferred Reporting Items for Systematic Review and Meta-Analysis Statement (PRISMA) guidelines were conducted in PubMed/Medline and Embase (Ovid) among studies published up to July 15th, 2020 (Supplementary Table S1) [35]. The used following keywords were used: "vaginal microbiome", "vaginal microbiota", "vaginal dysbiosis", "bacterial vaginosis", "Africa", "sub-Saharan Africa", "pregnant women", "pregnancy", and "pregnancy outcome". To ensure all of the available studies were included, keywords "Africa" or "sub-Saharan Africa" were switched to the individual name of the 48 sub-Saharan African countries (as defined by the World Bank) [36]. The exact Medical Subject Heading (MeSH) and Embase subject heading (Emtree) terms, free-text terms, and combinations of these keywords are compiled in Supplementary Table S1. Lastly, bibliographies of articles with information about BV or VMB were examined, even if articles were excluded, to retrieve potential articles via snowballing. Cohort and intervention studies that reported the VMB composition in women living in sub-Saharan African countries were reviewed. Inclusion criteria were: studies on human participants, pregnancy at the time of sampling, participants recruited in sub-Saharan African countries, as per World Bank classification [36]. Studies were excluded when data and analysis from pregnant and non-pregnant women were combined and when they performed culture-dependent VMB analysis and did not use molecular techniques. Reviews, case reports, abstracts from conferences and case series were also excluded. Studies were not restricted based on specific participant's characteristics, language or date of publication. The VMB results from molecular techniques reported at phylum, genus, or species level were included in this review. Characterization of vaginal microbial communities based on species' relative abundance or clustering reported by the studies were also summarized. Summary of VMB composition data from the intervention or case groups and placebo or non-intervention/control groups were reported separately in this review. Data from the non-interventional/control group might be representative of the VMB at the population-level. Data from the case group might inform on women's VMB status with specific health conditions, such as STIs, or taking compounds that can potentially modulate the VMB, such as medication or supplements.

\section{Summary and discussion of results}

\section{Study characteristics of vaginal microbiota studies}

Searches in PubMed and Embase databases yielded 475 records; an additional 135 records were further identified through snowballing. After the screening procedure, ten articles were included in this review (Supplementary Fig. S1). The characteristics of the retrieved studies are summarized in Table 1. These studies used different approaches to characterize the composition of VMB. However, all consistently clustered Lactobacillus species in other groups than anaerobic bacteria, e.g. Gardnerella species (Tables 2 and 3 and Fig. 2). Only one study characterized bacterial communities dominated by Streptococci and Staphylococci species, with a smaller proportion of Lactobacilli [37]. All included studies independently showed that a Lactobacillus-dominant VMB or VMB containing Lactobacilli are the most prevalent, followed by a more diverse anaerobedominant VMB in pregnant women living in South Africa, Burkina Faso, Rwanda, Kenya, Tanzania, Zambia, and Zimbabwe (Fig. 2). Different study populations were included (Table 1); two studies included results of known HIV-infected and HIV-uninfected women [38, 39]. One study included new cases of CT and TV infections in their case-control study [18], and another study tested the VMB of pregnant sex-workers [34]. One study had a group receiving folic-acid and iron supplements and another group only folic acid supplements [40].

In comparison, two other studies had given their intervention group probiotic (live organisms intended to have health benefits) capsules, and their control group placebo or no intervention [39, 41]. The rest of the studies did an observational or cross-sectional analysis of one or more populations $[16,17,42]$. Three of the studies used the common VMB classification method by CSTs, as first described by Ravel et al. [2]. Two other studies developed, via the same manner, the Rwanda (R)-cluster and Kenya, Rwanda South Africa, Tanzania (KRST)-clusters $[16,43]$. No consistent set of VMB clusters, particularly when it comes to the most diverse VMB, was identified across the included studies (Tables 2 and 3 ) $[2,16,38,40,42,43]$.

The vaginal microbiota throughout the pregnancy among pregnant African cohorts

Pregnancy is characterized by high circulating estrogen levels produced by the ovaries and later by the placenta 


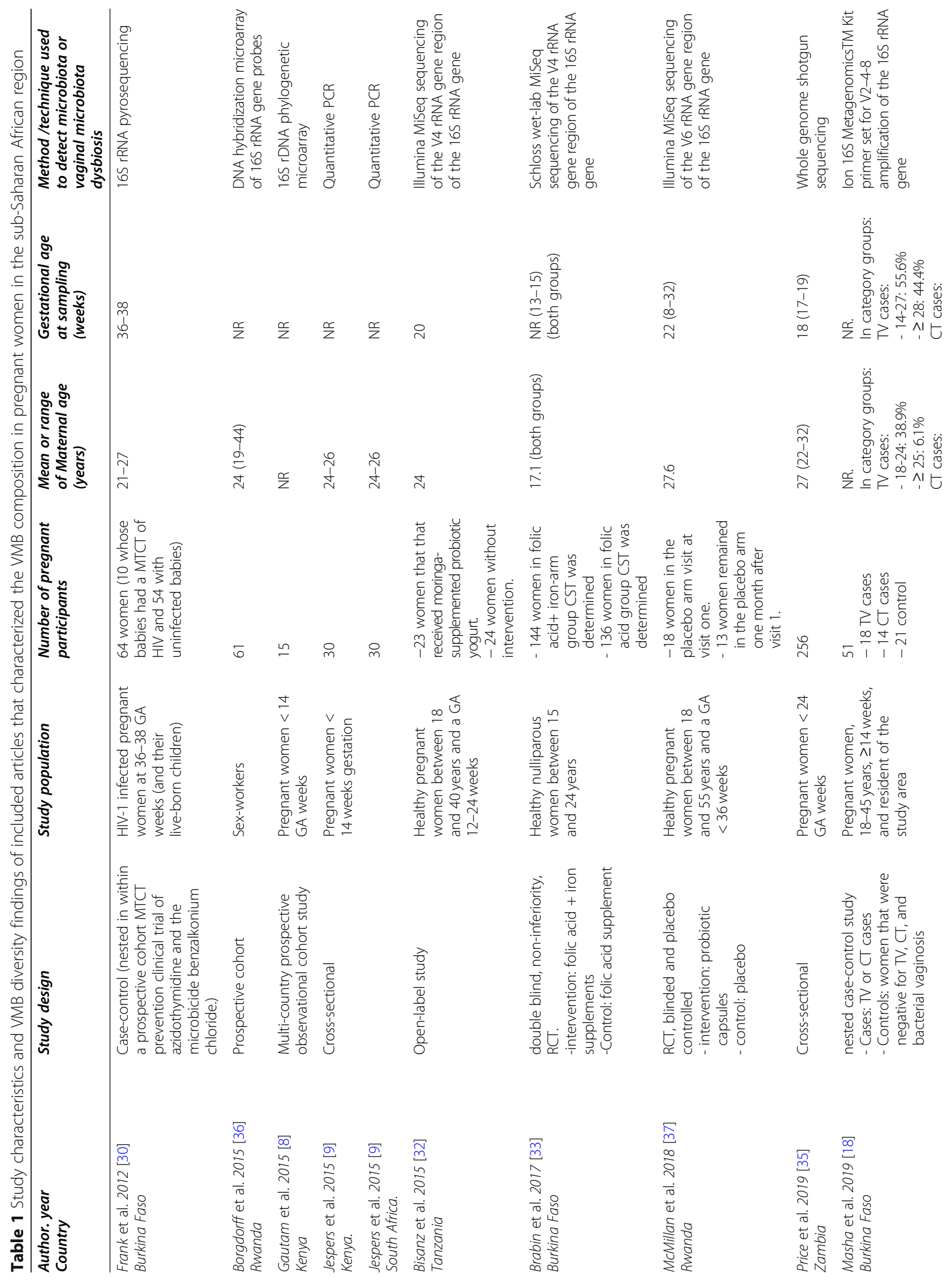




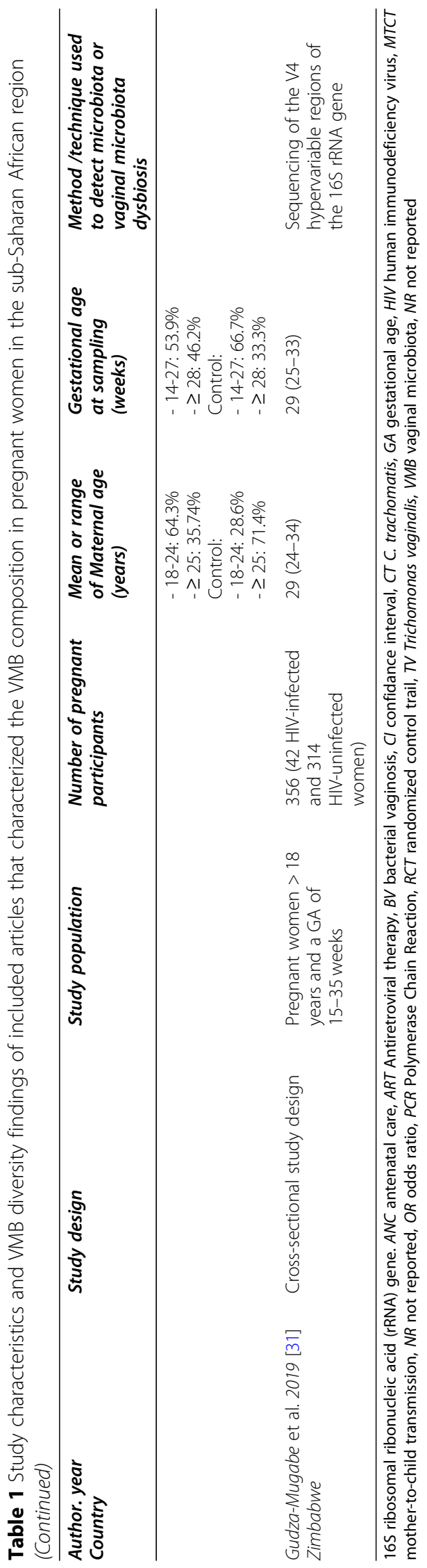


Table 2 Different types of vaginal microbiota Lactobacillaceae clusters in pregnant women in the sub-Saharan African region

\begin{tabular}{|c|c|c|c|c|c|c|c|c|}
\hline $\begin{array}{l}\text { Included articles that } \\
\text { used VMB clustering }\end{array}$ & Price et al. & Gudza et al. & Brabin et al. & Borgdorff et al. & Gautam et al. & Bisanz et al. & Frank et al. & Donders et al. \\
\hline Name of cluster & $\begin{array}{l}\text { Community } \\
\text { state type (CS }\end{array}$ & & & ClusterR & Cluster KRST & Not formulated & $\begin{array}{l}\text { Genus-level } \\
\text { clustering }\end{array}$ & $\begin{array}{l}\text { morpho-types } \\
\text { grades }\end{array}$ \\
\hline Lactobacillus dominant & & & & & & $\checkmark$ & Cluster 1 & Grade 1 \\
\hline L.crispatus dominant & CST-I & CST-I & CST-I & R-I & KRST-I & & & \\
\hline L.gasseri dominant & CST-\| & CST-II & & & & & & \\
\hline L.iners dominant & CST-III & CST-III & CST-III & $\mathrm{R}-\mathrm{II}$ & KRST-II & & & \\
\hline L.jensenii & CST-V & CST-V & & & & & & \\
\hline
\end{tabular}

CST community state types numeric system described by Ravel et al., [2]. R-clusters, vaginal microbiota cluster method in Rwandese women as described in Borgdorff et al. [36]. KRST-clusters, vaginal microbiota cluster method in Kenyan, Rwandese, South African and Tanzanian women as describe in Gautam et al. [8]

[44]. High levels of estradiol promote glycogen deposition in the vaginal epithelium that supports proliferation of various Lactobacillus species abundance [3, 45]. Both estrogen levels and microbiota composition change over the course of the pregnancy. Therefore, it is essential to consider the stage of pregnancy at sample collection when interpreting or comparing findings of different studies because VMB dysbiosis at the end of the pregnancy might not have the same impact as VMB dysbiosis earlier on $[1,46,47]$. Previous studies in North America showed that the diversity of $\mathrm{VMB}$ is highest during the first trimester of pregnancy and declines during the second and third trimester, possibly due to rising estrogen levels [48-50].

Two studies collected specimens in the first trimester $(<13$ weeks gestational age (GA)) (Fig. 1). In Kenyan women less than 14 weeks of gestation, the most common VMB cluster observed was $L$. iners-dominant with a high abundance of G. vaginalis, A. vaginae, and Prevotella species $(60 \%)$; this was followed by an L. crispatusdominant VMB cluster (20\%) [16]. Jesper et al. only reported the presence of microorganisms and not their relative abundance, and observed that the Lactobacillus genus was present in all 30 Kenyan pregnant women at 14 weeks of gestation, followed by P. bivia (97\%), L. iners (80\%), and G. vaginalis (50\%) [17]. These microorganisms were also observed in 30 South African pregnant women at 14 weeks of gestation. However, in this latter cohort, fewer women $(70 \%)$ had P. bivia in their VMB [17].

Two studies reported the VMB of pregnant women in the first and the second trimester (13-27 weeks GA) (Fig. 1). Bisanz et al. reported that all 42 tested pregnant Tanzanian women around 20 weeks of gestation (range 12-24 weeks GA) had a Lactobacillus-dominant VMB [39]. Between 13 and 15 GA weeks' Lactobacillaceae were again observed as the dominant VMB bacterial family among 478 Burkinabe pregnant, with a Lactobacillus-dominant VMB present in $78 \%$ of participants, $L$. crispatus in $44.9, \%$ and L. iners in $33.1 \%$ [40].
Moreover 96 HIV-infected and 158 HIV-uninfected Zambian pregnant women had a Lactobacillus-dominant VMB, either by L. iners (32\%) or L. crispatus (17\%) during the second trimester of the pregnancy [42] (Fig. 1). Ninety-five percent of women carried G. vaginalis, and $42 \%$ of women had a G. vaginalis-dominant VMB [42].

Masha et al. included samples collected in the second and third trimester ( $\geq 14$ weeks GA) and identified Lactobacillaceae as the dominant VMB bacterial family among 53 pregnant Kenyan women [25] (Fig. 1).

The two studies that reported the VMB composition at the third pregnancy trimester ( $>27$ weeks GA) also reported that most Burkinabe and Zimbabwean women had Lactobacillus-dominant VMB. In Burkina Faso, 47\% of women had a Lactobacillus-dominant VMB, while $37.5 \%$ of them had a VMB dominated by both Gardnerella species and L. iners [37]. In 314 HIV-uninfected and 42 HIV-infected Zimbabwe pregnant women, the Lactobacillus species were further identified. The majority of pregnant women in that cohort had a VMB dominated by $L$. crispatus (31\%), followed by a diverse VMB with various mixed anaerobes bacteria, including G. vaginalis (41\%) [38]. Another study identified Lactobacillaceae as the dominant VMB bacterial family among 38 Rwandan pregnant women across all trimesters (20 women who received Lactobacillus rhamnosus GR-1 and Lactobacillus reuteri $\mathrm{RC}-14$ and 18 women who received placebo) [41] (Fig. 1).

Lastly, Borgdorff et al. did not report sampling time [43] (Fig. 1). But like the other studies, they observed that during pregnancy Lactobacillus species were most prevalent among 21 Rwandese pregnant women, in particular L. iners [43]. The second most prevalent VMB composition in Rwandese pregnant women were women with diverse anaerobic communities and BVrelated bacteria, such as Gardnerella and Prevotella species [41, 43].

These sub-Saharan African studies, irrespective of sampling time and population reported that most women had a VMB Lactobacillus-dominant VMB 
Table 3 Different types of vaginal microbiota diversity clusters in pregnant women in the sub-Saharan African region

\begin{tabular}{|c|c|c|c|c|c|c|c|}
\hline Included articles that used VMB clustering & $\begin{array}{l}\text { Price } \\
\text { et al. }\end{array}$ & $\begin{array}{l}\text { Gudza } \\
\text { et al. }\end{array}$ & $\begin{array}{l}\text { Brabin } \\
\text { et al. }\end{array}$ & $\begin{array}{l}\text { Borgdorff } \\
\text { et al. }\end{array}$ & $\begin{array}{l}\text { Gautam } \\
\text { et al. }\end{array}$ & $\begin{array}{l}\text { Frank } \\
\text { et al. }\end{array}$ & $\begin{array}{l}\text { Donders } \\
\text { et al. }\end{array}$ \\
\hline Name of cluster & \multicolumn{2}{|c|}{$\begin{array}{l}\text { Community state } \\
\text { type (CST) }\end{array}$} & & ClusterR & Cluster KRST & $\begin{array}{l}\text { Genus-level } \\
\text { clustering }\end{array}$ & $\begin{array}{l}\text { morpho-types } \\
\text { grades }\end{array}$ \\
\hline $\begin{array}{l}\text { Diversity group: Higher proportions of strictly anaerobic } \\
\text { bacteria, including Prevotella, Dialister, Atopobium, } \\
\text { Gardnerella, Megasphaera, Peptoniphilus, Sneathia, } \\
\text { Eggerthella, Aerococcus, Finegoldia, and Mobiluncus. }\end{array}$ & \multicolumn{3}{|l|}{ CST-IV } & & & & \\
\hline Diversity group: High abundances of Gardnerella, & & & & R-III & KRST-III & & \\
\hline
\end{tabular}

Prevotella and Atopobium species and lower abundances of Dialister, Megasphaera and Mobiluncus species and BVAB1 and the presence of a lower abundance of $L$. iners.

Diversity group: Higher proportions of strictly anaerobic bacteria, especially $G$ vaginalis, BVAB 1 .

Diversity group: Higher proportions of strictly anaerobic bacteria, especially $G$ vaginalis, L iners, and A vaginae.

Diversity group: High abundances of Gardnerella, Prevotella and Atopobium species and lower abundances of Dialister, Megasphaera and Mobiluncus species and BVABI, L. iners, and high abundance Gardnerella genus.

Diversity group: High abundances of Gardnerella, Prevotella and Atopobium species and lower abundances of Dialister, Megasphaera and Mobiluncus species and BVAB1, and lower total bacterial abundance than the other mixed anaerobic clusters.

Diversity group: High abundances of Gardnerella, Prevotella and Atopobium species and lower abundances of Dialister, Megasphaera and Mobiluncus species and BVABT, L. iners, and highest levels of Prevotella species.

Diversity group: Higher proportions of strictly anaerobic CST-IV-II bacteria and $G$. vaginalis, and A. vaginae.

Diversity group: Higher proportions of strictly anaerobic CST-IV-III bacteria other than $G$. vaginalis and A. vaginae.

Diversity group: pooled dysbiotic clusters.

Diversity group: Mixed of variety of genera, dominated by Gardnerella spp. and Lactobacillus spp.

Diversity group: low Lactobacillus spp. and diverse anaerobic groups (eg, Prevotella, Sneathia, Peptostreptococcus)

Diversity group: lesser Lactobacillus spp mixed with other bacteria.

Diversity group: Absence of Lactobacillus spp or overwhelming presence of other bacteria (not specified).

Diversity group: Dominated by coagulase-negative staphylococci (S. haemolyticus and S. epidermidis) with lesser quantities of lactobacilli
CST-IV-I

CST-IVA

CST-IVB

\section{CSTIVB}

(n)




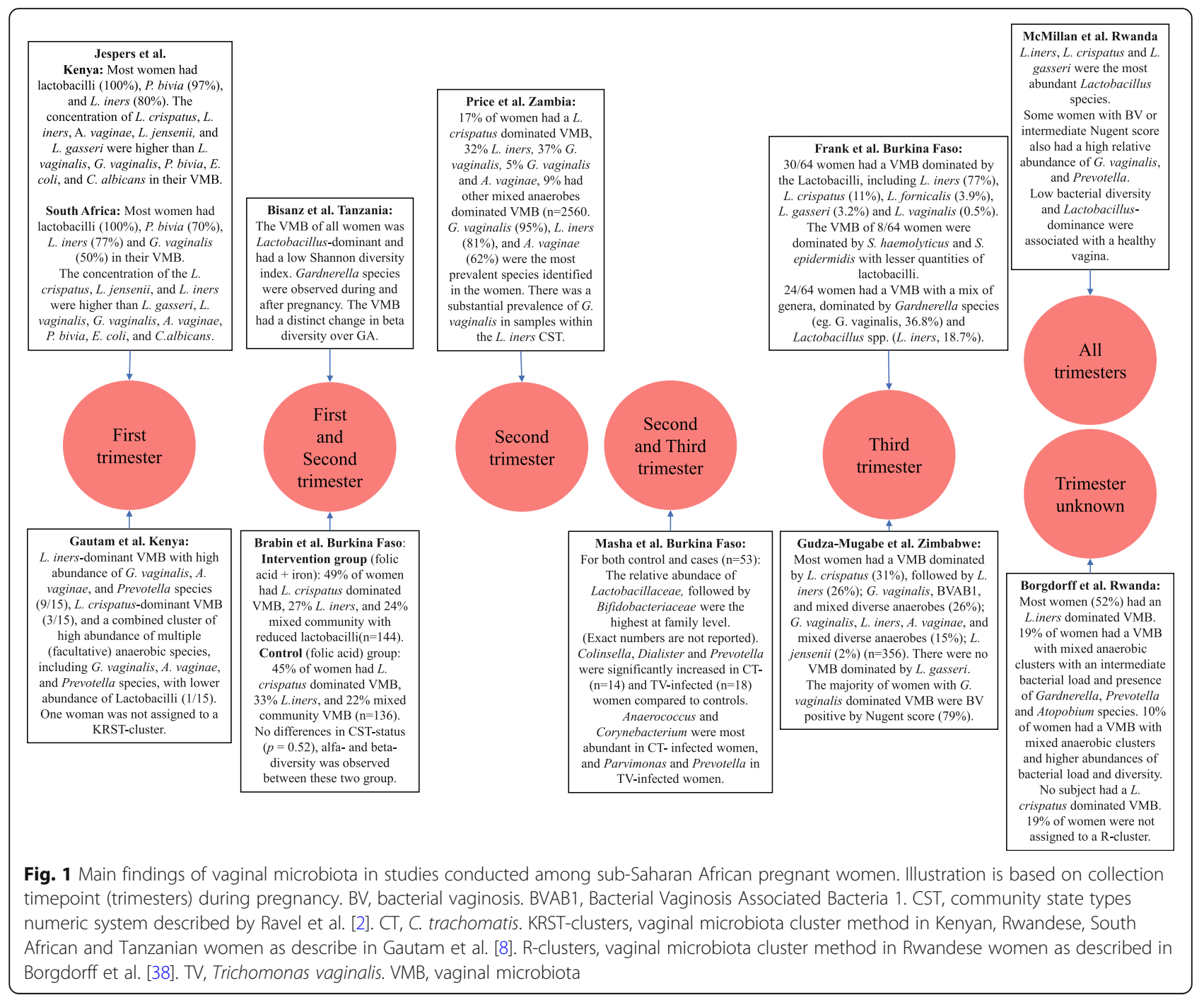

Future longitudinal studies containing information on the VMB composition before, during, and after pregnancy might provide information on the VMB composition changes between these periods and whether the $\mathrm{VMB}$ before pregnancy influences the VMB during pregnancy in sub-Saharan African populations.

\section{Vaginal microbiota communities by clustering}

To date, there is no consensus on how best to classify VMB communities [46] (Tables 2 and 3). Most of the studies in our review showed that a Lactobacillus-dominant $\mathrm{VMB}$ is the most prevalent vaginal microbiota in tested pregnant women despite differences in methodology and definitions $[16,25,37-43,52]$. This evidence is in line with findings from other populations in Asia, North-America, and Europe [3, 19, 53]. Independent of the type of clusters used to classify the VMB and the gestational age at sampling when speciated, $L$. iners was the most pervasive Lactobacillus species detected, followed by L. crispatus [16, 17, 37, 39-42] (Fig. 2). Unlike pregnant cohorts in Europe and North America, the second most prevalent $\mathrm{VMB}$ composition detected in Burkina Faso, Rwanda, and Zambia were diverse VMB clusters with high abundances of anaerobic bacteria, in most cases G. vaginalis [3, 19, 37, 42, 43]. Several factors have been proposed to contribute to women becoming tolerant to a non-Lactobacillus dominant vaginal milieu, such as genetic variation, like polymorphism in the immune and hormone-response genes, for instance single nucleotide polymorphisms in toll-like receptor (TLR)-4 (rs1554973 and rs7856729 or anti-inflammatory interleukin10 (IL10-819 T/T and IL10-1082 A/A) [54-59]. Several studies observed that host genetics, via polymorphism in immune-related genes, increases colonization of specific bacteria in the vagina [60-63]. Interestingly, women with African ancestry carry polymorphisms in cytokine genes, making them more susceptible to inadequately respond to lipopolysaccharides (LPS) and develop vaginal dysbiotic 


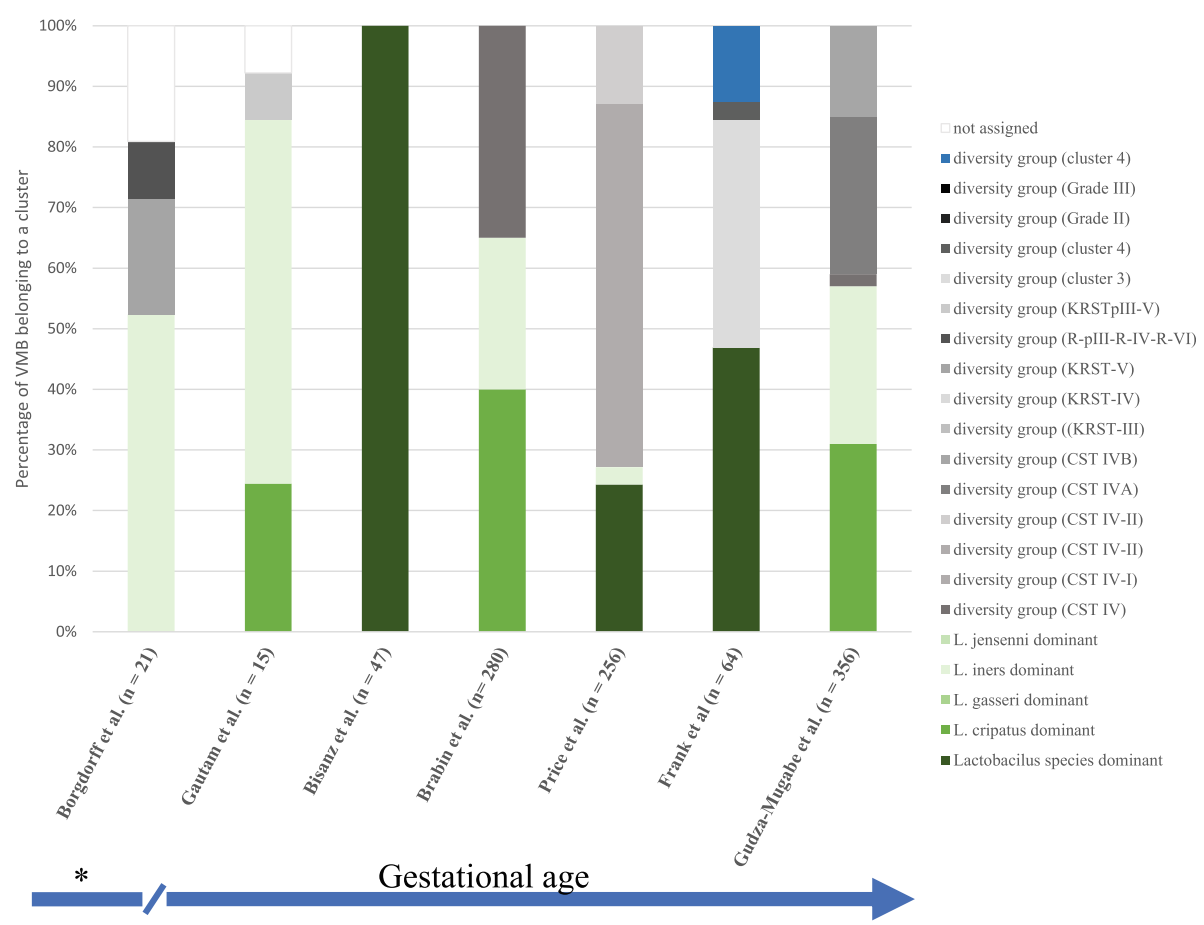

Fig. 2 Percentages of vaginal microbiota clusters from pregnant women living in sub-Saharan Africa. *Unknown time of exact sampling. Bacterial names and clusters abbreviations are corresponding to data in Table 2

conditions, such as BV [24, 64]. The high frequency of a more diverse $\mathrm{VMB}$ and anaerobic composition observed among sub-Saharan African (pregnant) women are in agreement with the high prevalence of BV (proximally 40\%) also observed among sub-Saharan African women [14, 33, 55]. Early-life exposure to nonLactobacillus dominant VMB may mediate the host immunological reaction to microbiota species and nurture immunological tolerance [55]. Genetic variations and host immunological mediators may partially clarify the VMB composition variability across ethnicities, but more evidence is warranted $[3,13,64]$.

In pregnant Zimbabwean women, the prevalence of $L$. crispatus-dominant VMB was slightly higher than the prevalence of $L$. iners-dominant $\mathrm{VMB}$ or $\mathrm{VMB}$ with a high abundance of $G$. vaginalis, Bacterial vaginosisassociated bacterium 1 (BVAB1), and mixed diverse anaerobic bacteria [38]. Interestingly, none of the pregnant Rwandan sex-workers had an L. crispatus dominant VMB [43]. These observations are in line with results from pregnant African-American women in which $L$. iners and diverse anaerobic VMB were the most dominant VMB [13, 51]. Unfortunately, Jesper et al., Bisanz et al., and Masha et al. did not report the dominant species in the VMB of their South-African, Kenyan, Tanzanian, or Burkinabe pregnant cohort [17, 25, 39]. Masha et al. and Bisanz et al. independently characterized the VMB based on the genus and reported separately that the relative abundance of the Lactobacillus genus was the highest in their cohort from Burkina Faso and Tanzania, respectively $[25,39]$. Their findings are in concordance with the results of Brabin et al. also reporting a high prevalence of Lactobacillus-dominant VMB clusters (L. crispatus and L. iners) in Burkinabe women [40]. Jesper et al. did report that all pregnant women tested in both countries had Lactobacillus genus in their $\mathrm{VMB}$, P. bivia $(70 \%)$, and G. vaginalis $(50 \%)$ were also detected in the majority of women in South Africa [17]. In Kenya, $97 \%$ of pregnant women had P. bivia present in their VMB [17]. Petrova et al. reviewed and proposed how the various VMB composition clusters, as classified by CSTs, can be associated with vaginal health or dysbiosis [9]. It has been suggested multiple times that VMB dominated by L. crispatus, L. gasseri, or L. jensenii relates to a healthy vaginal state and an overgrowth of anaerobes as Gardnerella, Atopobium, and Prevotella species most likely contributes to a dysbiotic-BV state. However, it is unclear whether the VMB clusters consistent with the presence of modest Lactobacillus species with a higher relative abundance of anaerobic bacteria, such as BVAB1, G. vaginalis, A. vaginae, but without an overgrowth of anaerobes bacteria, associate with a healthy vaginal state or with a transitional state of the vaginal milieu to a BV state [9]. Shifts from eubiosis to dysbiosis, and vice-versa, remain unpredictable processes, and their causes are not yet understood [65]. 
Moreover, it is unclear what type of vaginal state is associated with a $L$. iners-dominated VMB [8]. Unlike the other Lactobacillus species, L. iners does secrete some amounts of hydrogen peroxide $\left(\mathrm{H}_{2} \mathrm{O}_{2}\right)$, but not D-lactic acid, both common secretory products of most Lactobacilli [10]. L. iners also been shown to promote the growth of $E$. coli and $G$. vaginalis biofilm and can produce pore-forming toxin similar to G. vaginalis can induce lysing of erythrocytes [66-69]. Several data showed that VMB-dominated by L. iners are more likely to transition to a BV-associated VMB and offer limited protection against vaginal dysbiosis, clearance of urogenital pathogens, and might be a risk factor to adverse pregnancy outcomes [10, 70, 71]. For example in a cohort from London, Lactobacillus iners dominance at 16 weeks of gestation was significantly associated with both a short cervix $<25 \mathrm{~mm}$ and preterm birth $<34+0$ weeks [72]. However, the debate about what composition defines a healthy and unhealthy VMB is ongoing, especially across different ethnic populations. Thus, further investigation should determine what the exact role of an L. iners-dominant VMB and a diverse VMB are on pregnancy outcomes, especially in the sub-Saharan population where the prevalence of these VMB compositions are high.

\section{The VMB composition of women carrying a sexually transmitted pathogen}

Globally, 70\% of all people living with HIV live in subSaharan Africa [24, 55, 73]. The articles by Frank et al. and Price et al. provide an essential insight into the role of HIV in the VMB of pregnant women living in the region with the global highest burden of HIV and other STIs [37, 42]. A high frequency of vaginal dysbiosis were observed in both studies (Fig. 2). In non-pregnancy studies it was reported that the most common clinical diagnosis of BV was associated with a $60 \%$ increase in the risk of acquiring HIV after exposed, and that presence of L. crispatus associates with suppression of viral replication and virus inactivation [74-77]. As mentioned before, Lactobacillus species, other than L. iners, are important to vaginal health as they produce antimicrobial molecules. For instance, $\mathrm{H}_{2} \mathrm{O}_{2}$ and other bacteriocins can destroy urogenital pathogens, and lactic acid can inhibit pathogenic bacteria's growth and disrupt the bacterial cell membranes, thereby contributing to the host immune response to bacterial liposaccharides [74]. Lactic acid is thought to be the main regulator of "healthy" vaginal function, rather than Lactobacillus species, since the vaginal tracts of asymptomatic women with a diverse $\mathrm{VMB}$ are also dominated by taxa that produce lactic acid [9]. Women with low production of lactic acid and vaginal dysbiosis have a higher risk of acquiring STI when exposed and of adverse reproductive and obstetric sequelae $[74,78]$.
Luckily, antiretroviral therapy (ART) and associated approaches for the prevention of Mother-To-Child Transmission of HIV infection (MTCT) are becoming more standard practice in most sub-Saharan African settings [79-82]. Price et al. observed that the prevalence of anaerobes dominated VMB, or CST IV, was higher among HIV-infected women taking ART prior to conception (63.5\%) and among the non-ART group (85.3\%), compared to HIV uninfected participants (45.3\%) [42]. They also reported an association between an anaerobicdominant VMB, maternal HIV infection, and ART timing before or during the pregnancy [42]. Future studies are needed to investigate whether specific interventions, such as ART, antibiotics, and probiotics, can modulate the VMB into a healthy state, which might be different based on ethnicity, and might lower the risk of HIV acquisition and MTCT.

Besides HIV, other STIs are highly endemic in sub-Saharan Africa, including TV and CT, and have been associated multiple times with vaginal dysbiosis, lower Lactobacilli levels, and alkaline vaginal milieu [74, 83-85]. Brabin et al. reported in their study that TV and BV were associated $(P<0.01)$ with a more diverse and anaerobic VMB composition in Burkinabe pregnant women [40].

The included study by Masha et al. characterized the VMB profiles in TV- and CT-infected, and non-infected pregnant women in Kenya [25]. Lactobacilli were the most abundant in all three groups. In CT-infected pregnant women, Anaerococcus and Corynebacterium were most abundant compared to TV-infected women or controls. In line with other studies' observations, in TVinfected women, Parvimonas and Prevotella were most abundant and significantly more present compared to controls [86]. The anaerobes Prevotella, Anaerococcus, Parvimonas (formerly Peptostreptococcus), and Dialister have been observed frequently in women with vaginal dysbiosis (with CST IV) or BV; however, it is still unclear what the role of Parvimonas, Anaerococcus, Dialister, and Corynebacterium is in the pathology of TV and CT infections and its effect on the VMB state [1, 25]. Therefore, the interplay between VMB and STIs should be further investigated in in-vitro models or samples from women living in a high-risk population. Such findings are crucial for vulnerable populations with high STI prevalence, such as pregnant women in sub-Saharan Africa countries.

\section{Effect of probiotics, vitamins, and mineral on the VMB during pregnancy}

Besides the high burden of STIs, malnutrition, or undernourishment is also prevalent in low-income areas in sub-Saharan Africa, especially among pregnant women [87]. Currently, vitamins and minerals (especially folic 
acid and iron) are recommended during pregnancy for every woman across sub-Saharan Africa, particularly for undernourished women. Brabin et al. did not observe any association between VMB composition, extra iron supplements, and host iron status in pregnant Burkinabe women [40].

McMillan et al. and Bisanz et al. examined whether probiotics containing specific Lactobacilli would alter the VMB composition during pregnancy in and Tanzanian women, respectively $[39,41]$. Unfortunately, VMB data solely from the control group was not reported in Bisanz et al. [39]. However, their data were still included in this review because, similar to McMillan et al., they explicitly mentioned that there was no difference in the VMB composition between the probiotic group and the control group [39, 41]. Interestingly, McMillan et al. did report that the Rwandese women in the calcium carbonate placebo group were significantly more likely to give birth preterm than women in their probiotic group [41]. However, both groups' sample sizes were too small to draw a final conclusion [41]. The relationship between these pregnancy outcomes with their respective $\mathrm{VMB}$ was not further analyzed or discussed [41].

Different Lactobacillus-based probiotics, made with mixtures of Lactobacillus species, Bifidobacterium, and Streptococcus strains have been studied [23, 88]. Lately, the use of probiotic (containing Lactobacillus strains, mostly Lactobacillus rhamnosus) have been claimed to restore Lactobacillus-dominated VMB in women with BV [89-91]. The two included intervention studies also proved that probiotic supplements are safe for use. However the probiotic adherence (important feature of probiotics associated with their potential for colonization) to the human vagina mucus and the cost-effective strategies for its implementation should also be considered [39, 41]. Ideally, there is need for a cost-effective treatment that targets specific pathobionts (commensal microorganisms with pathogenic potential) or dysbiosis-associated anaerobes while sparing Lactobacillus species could restore VMB eubiosis and simultaneously nourish malnourished (pregnant) women in resources-constrained settings.

\section{VMB characteristics and pregnancy outcome}

VMB characteristics, or presence of pathobionts, have been linked to various maternal, fetal health issues and adverse pregnancy outcomes, primarily preterm birth, but also chorioamnionitis, premature rupture of membranes, stillbirth, preeclampsia [21, 92-96]. The retrieved studies that analysed the VMB by molecular approaches did not investigate the association between VMB and an adverse pregnancy outcome. To our knowledge, only one culture-based study analysed the relationship between VMB and late pregnancy complications (after 20 weeks' gestation) in sub-Saharan African pregnant women, to date. Donders et al. observed that South African women with little or no Lactobacilli were 3.6 times more likely to have an infant with low birthweight $(<2 \mathrm{~kg})$ compared to women with a high abundance of Lactobacilli [97]. Discussion on the mechanisms behind this possible causal effect of VMB dysbiosis on several adverse pregnancy outcomes were previously reviewed and are outside the scope of this review [1,98]. Nevertheless, there is a need for future studies using newer molecular diagnostic techniques to confirm these findings and determine whether low birthweight, preterm birth, or other adverse pregnancy outcomes are generally associated with maternal VMB composition in sub-Saharan African women.

\section{Limitations and future considerations}

The heterogeneity of results included in this review is high since different study designs were included, different study populations (from sex-workers to people with low sexual and reproductive risk behavior), and studies that used diverse molecular approaches. Pyrosequencing and Illumina MiSeq sequencing of the $16 \mathrm{~S}$ ribosomal ( $\mathrm{r}$ ) RNA gene allow for an unprecedented high-resolution detection of the microbiota [99]. However, microarray approaches, like that used by Borgdorff et al., cannot detect genes of species that are not a priori included in the array [43]. Furthermore, comparing $16 \mathrm{~S}$ rRNA gene sequencing results from different studies should also be done carefully since there is a lack of standardization in methodologies used to prepare samples and analyze the VMB results [100]. Also, each variable (V)16S rRNA region has a different resolution to identify bacterial strains; for instance, the V2-V3 fragment has the highest resolution to detect species and genera [101]. These technical differences can also result in under- or overrepresentation of a bacterial taxon $[46,102]$.

The present review identified many research gaps. It is still unclear what the mechanism behind a healthy and balanced VMB is [46], as it is the role of common vaginal bacteria in pregnant sub-Saharan African women. Furthermore, the number of different dysbiotic clusters reported in this review (Table 2) and the high prevalence of $L$. iners and G. vaginalis among pregnant sub-Saharan women might indicate eubiosis or healthy VMB, rather than a transitional or abnormal VMB as seen in other ethnic populations $[42,103]$. A multi-country study and a more tailored sub-classification of the VMB characterized by high diversity might be more relevant in the African population than in other populations. The clinical and biological relevance of defining the VMB by clusters also remains to be further investigated in women from sub-Saharan Africa [46]. Deciphering the relationship between host, VMB, and the immune system can even provide therapeutic intervention strategies, 
for instance, pro- or antibiotics, that might benefit maternal health [1]. To do so in a more personalized manner, the host ethnicity's role should also be taken into account.

Furthermore, the role of pathogens on VMB composition, especially STIs that have a high incidence and prevalence, the latest estimate was made in 2012, where in Africa there were 357 million new episodes of four curable STIs (chlamydia, gonorrhoea, syphilis, and trichomoniasis) [104]. These STIs also cause a high burden of disease in African communities, should also be further evaluated [24, 25, 38, 42]. Moreover, interventions with dietary strategies, including human colostrum/milk or prebiotics/probiotics, have already been studied in preterm infant and early pregnancy development after in-vitro fertilization [23, 88]. Considering the possible association between individual VMB states and adverse pregnancy outcomes, affordable and easily accessible interventions that beneficially modulate the VMB should be evaluated and are urgently needed [21].

\section{Conclusion}

This study provides an overview of the current knowledge of VMB composition in pregnant women living in seven sub-Saharan Africa. It remains challenging to compare VMB characteristics across studies performed in this region since populations and experimental methods vary considerably [24]. Nevertheless, the evidence provided here highlights that most sub-Saharan African studies reported pregnant women having VMB dominated by $L$. iners or more diverse anaerobic communities, mostly with a high abundance of G. vaginalis. Future research should investigate the pathogenesis and host-immunological role of the VMB bacteria on various health conditions and outcomes in more detail. To allow for analysis across studies, consensus on how to test and report VMB composition in sub-Saharan African women should be reached for a better comparison of data sets. Furthermore, a large shared multi-county/international database could also help to minimize these problems. A systematic comparison of evidence across countries will help provide substantial qualitative evidence for public health strategies to improve reproductive and maternal health in sub-Saharan Africa.

\footnotetext{
Abbreviations

VMB: Vaginal microbiota; CST: Community State Types; BV: Bacterial vaginosis; STIs: Sexually transmitted infections; NG: Neisseria gonorrhoeae; CT: C. trachomatis; TV: Trichomonas vaginalis; HIV: Human immunodeficiency virus; PRISMA: Preferred Reporting Items for Systematic Review and Meta-Analysis Statement; MeSH: Medical Subject Heading; Emtree: Embase subject heading; R-cluster: Rwanda cluster; KRST-cluster: Kenya, Rwanda South Africa, Tanzania cluster; GA: Gestational age; TLR: Toll-like receptor; IL: Interleukin; LPS: Lipopolysaccharides; BVAB1: Bacterial vaginosis-associated bacterium 1; ART: Antiretroviral therapy
}

\section{Supplementary Information}

The online version contains supplementary material available at https://doi. org/10.1186/s12884-021-04072-1.

Additional file 1: Figure S1. PRISMA based Flow diagram displaying the study selection [28].

Additional file 2: Table S1. Search strategies and hits based on searches last conducted on July 15, 2020 [29].

\section{Acknowledgements}

We are grateful to Meghan Suiters for her assistance with screening eligible articles through titles and abstracts.

\section{Authors' contributions}

NCA Juliana performed the systematic search and the screening. NCA Juliana and $E$ Ambrosino retrieved potential studies for the inclusion of the study. NCA Juliana wrote the introduction, materials, methods, results, and discussion sections. S Al-Nasiry, AE Budding, and SA Morré critically reviewed the manuscript. RPH Peters and E Ambrosino conceived the original idea, supervised the study, critically reviewed and edited the manuscript. All authors contributed to the final versions of the manuscript. The author(s) read and approved the final manuscript.

\section{Funding}

This review did not receive a specific grant from funding agencies in the public, commercial, or not-for-profit sectors.

Availability of data and materials

Not applicable.

\section{Declarations}

Ethics approval and consent to participate

Not required.

Consent for publication

Not applicable.

\section{Competing interests}

Andries E. Budding paid advisor to ArtPred BV. Other Authors declare no competing interests.

\section{Author details}

'Department of Genetics and Cell Biology, Faculty of Health, Medicine and Life Sciences, Research School GROW (School for Oncology \& Developmental Biology), Institute for Public Health Genomics, Maastricht University, Maastricht, Netherlands. ${ }^{2}$ Department of Medical Microbiology, University of Pretoria, Pretoria, South Africa. ${ }^{3}$ Department of Medical Microbiology, School for Public Health and Primary Care (CAPRHI), Maastricht University, Maastricht, Netherlands. ${ }^{4}$ Research Unit, Foundation for Professional Development, East London, South Africa. ${ }^{5}$ Department of Obstetrics and Gynecology, GROW School of Oncology and Developmental Biology, Maastricht University Medical Centre (MUMC), Maastricht, Netherlands. ${ }^{6}$ Inbiome, Amsterdam, Netherlands. ${ }^{7}$ Laboratory of Immunogenetics, Department Medical Microbiology and Infection Control, Location AMC, Amsterdam UMC, Amsterdam, Netherlands.

Received: 15 March 2021 Accepted: 20 August 2021

Published online: 03 September 2021

References

1. Al-Nasiry S, Ambrosino E, Schlaepfer M, Morré SA, Wieten L, Voncken JW, et al. The interplay between reproductive tract microbiota and immunological system in human reproduction. Front Immunol. 2020;11:378. https://doi.org/10.3389/fimmu.2020.00378.

2. Ravel J, Gajer P, Abdo Z, Schneider GM, Koenig SSK, McCulle SL, et al. Vaginal microbiome of reproductive-age women. Proc Natl Acad Sci U S A. 2011;108(SUPPL. 1):4680-7. https://doi.org/10.1073/pnas.1002611107.

3. Maclntyre DA, Chandiramani M, Lee YS, Kindinger L, Smith A, Angelopoulos $\mathrm{N}$, et al. The vaginal microbiome during pregnancy and the postpartum 
period in a European population. Sci Rep. 2015;5(1). https://doi.org/10.1038/ srep08988.

4. van de Wijgert JHHM. The vaginal microbiome and sexually transmitted infections are interlinked: consequences for treatment and prevention. PLoS Med. 2017;14(12):e1002478. https://doi.org/10.1371/journal.pmed.1002478.

5. Ravel J, Gajer P, Abdo Z, Schneider GM, Koenig SSK, Mcculle SL, et al. Vaginal microbiome of reproductive-age women; 2011. https://doi.org/10.1 073/pnas.1002611107.

6. Sakai M, Ishiyama A, Tabata M, Sasaki Y, Yoneda S, Shiozaki A, et al. Relationship between cervical mucus interleukin-8 concentrations and vaginal bacteria in pregnancy. Am J Reprod Immunol. 2004;52(2):106-12. https://doi.org/10.1111/j.1600-0897.2004.00203.x.

7. Nikolaitchouk N, Andersch B, Falsen E, Strömbeck L, Mattsby-Baltzer I. The lower genital tract microbiota in relation to cytokine-, SLPI- and endotoxin levels: application of checkerboard DNA-DNA hybridization (CDH). APMIS. 2008;116(4):263-77. https://doi.org/10.1111/j.1600-0463.2008.00808.x.

8. Van De Wijgert JHHM, Borgdorff H, Verhelst R, Crucitti T, Francis S, Verstraelen $\mathrm{H}$, et al. The vaginal microbiota: what have we learned after a decade of molecular characterization? PLoS One. 2014;9(8):e105998. https:// doi.org/10.1371/journal.pone.0105998.

9. Petrova MI, Reid G, Vaneechoutte M, Lebeer S. Lactobacillus iners: friend or foe? Trends Microbiol. 2017;25(3):182-91. https://doi.org/10.1016/j.tim.201 6.11.007.

10. Vaneechoutte M. Lactobacillus iners, the unusual suspect. Res Microbiol. 2017;168(9-10):826-36. https://doi.org/10.1016/j.resmic.2017.09.003.

11. Gupta P, Singh MP, Goyal K. Diversity of vaginal microbiome in pregnancy: deciphering the obscurity. Front Public Health. 2020;8:326. https://doi.org/1 0.3389/fpubh.2020.00326

12. Fettweis JM, Serrano MG, Brooks JP, Edwards DJ, Girerd PH, Parikh HI, et al. The vaginal microbiome and preterm birth. Nat Med. 2019;25(6):1012-21. https://doi.org/10.1038/s41591-019-0450-2.

13. Hyman RW, Fukushima M, Jiang H, Fung E, Rand L, Johnson B, et al. Diversity of the vaginal microbiome correlates with preterm birth. Reprod Sci. 2014;21(1):32-40. https://doi.org/10.1177/1933719113488838.

14. Zhou X, Brown CJ, Abdo Z, Davis CC, Hansmann MA, Joyce P, et al. Differences in the composition of vaginal microbial communities found in healthy Caucasian and black women. ISME J. 2007;1(2):121-33. https://doi. org/10.1038/ismej.2007.12.

15. Serrano MG, Parikh HI, Brooks JP, Edwards DJ, Arodz TJ, Edupuganti L, et al. Racioethnic diversity in the dynamics of the vaginal microbiome during pregnancy. Nat Med. 2019;25(6):1001-11. https://doi.org/10.1038/s41591-01 9-0465-8.

16. Gautam R, Borgdorff H, Jespers V, Francis SC, Verhelst R, Mwaura M, et al. Correlates of the molecular vaginal microbiota composition of African women. BMC Infect Dis. 2015;15(1):86. https://doi.org/10.1186/s12879-0150831-1.

17. Jespers V, van de Wijgert J, Cools P, Verhelst R, Verstraelen H, DelanyMoretlwe $\mathrm{S}$, et al. The significance of Lactobacillus crispatus and $\mathrm{L}$. vaginalis for vaginal health and the negative effect of recent sex: a cross-sectional descriptive study across groups of African women. BMC Infect Dis. 2015; 15(1):115. https://doi.org/10.1186/s12879-015-0825-z.

18. Anahtar MN, Byrne EH, Doherty KE, Bowman BA, Yamamoto HS, Soumillon $M$, et al. Cervicovaginal Bacteria are a major modulator of host inflammatory responses in the female genital tract. Immunity. 2015;42(5):965-76. https:// doi.org/10.1016/j.immuni.2015.04.019.

19. DiGiulio DB, Callahan BJ, McMurdie PJ, Costello EK, Lyell DJ, Robaczewska A, et al. Temporal and spatial variation of the human microbiota during pregnancy. Proc Natl Acad Sci U S A. 2015;112(35):11060-5. https://doi.org/1 0.1073/pnas.1502875112.

20. Ma B, Forney LJ, Ravel J. Vaginal microbiome: rethinking health and disease. Annu Rev Microbiol. 2012;66(1):371-89. https://doi.org/10.1146/annurevmicro-092611-150157.

21. Stout MJ, Zhou Y, Wylie KM, Tarr PI, Macones GA, Tuuli MG. Early pregnancy vaginal microbiome trends and preterm birth. Am J Obstet Gynecol. 2017; 217:356.e1-356.e18.

22. Doyle R, Gondwe A, Fan YM, Maleta K, Ashorn P, Klein N, et al. A Lactobacillus-deficient vaginal microbiota dominates postpartum women in rural Malawi. Appl Environ Microbiol. 2018;84(6). https://doi.org/10.1128/A EM.02150-17.

23. Singer $M$, Borg M, Ouburg S, Morré SA. The relation of the vaginal microbiota to early pregnancy development during in vitro fertilization treatment-a meta-analysis. J Gynecol Obstetr Hum Reprod. 2019;48(4):2239. https://doi.org/10.1016/j.jogoh.2019.01.007.

24. Bayigga L, Kateete DP, Anderson DJ, Sekikubo M, Nakanjako D. Diversity of vaginal microbiota in sub-Saharan Africa and its effects on HIV transmission and prevention. Am J Obstet Gynecol. 2019.

25. Masha SC, Cools P, Descheemaeker P, Reynders M, Sanders EJ, Vaneechoutte M. Urogenital pathogens, associated with trichomonas vaginalis, among pregnant women in Kilifi, Kenya: a nested case-control study. BMC Infect Dis. 2018;18(1):549. https://doi.org/10.1186/s12879-01 8-3455-4.

26. Watson-Jones $D, \ldots$ HW-B of the W, 2007 undefined. Adverse birth outcomes in United Republic of Tanzania: impact and prevention of maternal risk factors. SciELO Public Heal https://www.scielosp.org/article/ bwho/2007.v85n1/9-18/en/. Accessed 23 Mar 2020.

27. WHO, UNICEF, UNFPA, World Bank Group, United Nations Population Division. Global health observatory. Global Strategy for Women's, Children's and Adolescents' Health (2016-2030): WHO. p. 2019. https://www.who.int/ reproductivehealth/publications/maternal-mortality-2000-2017/en/. Accessed 27 Jul 2020

28. Chawanpaiboon S, Vogel JP, Moller AB, Lumbiganon P, Petzold M, Hogan D, et al. Global, regional, and national estimates of levels of preterm birth in 2014: a systematic review and modelling analysis. Lancet Glob Health. 2019; 7(1):e37-46. https://doi.org/10.1016/S2214-109X(18)30451-0.

29. Davey DL, Shull HI, Billings JD, Wang D, Adachi K, Klausner JD. Prevalence of curable sexually transmitted infections in pregnant women in low- and middle-income countries from 2010 to 2015: a systematic review. Sex Transm Dis. 2016;43(7):450-8. https://doi.org/10.1097/OLQ.0000000000000460.

30. UNAIDS. Africa prepares to eliminate mother-to-child transmission of HIV by 2015. 2010. https://www.unaids.org/en/resources/presscentre/fea turestories/2010/may/20100526pmtct. Accessed 28 Sep 2020.

31. Blackstone SR, Nwaozuru U, Iwelunmor J. Antenatal HIV testing in subSaharan Africa during the implementation of the millennium development goals: a systematic review using the PEN-3 cultural model. Int Q Community Health Educ. 2018;38(2):115-28. https://doi.org/10.1177/0272684 X17749576.

32. Gupta VK, Paul S, Dutta C. Geography, ethnicity or subsistence-specific variations in human microbiome composition and diversity. Front Microbiol. 2017:8:1162. https://doi.org/10.3389/fmicb.2017.01162.

33. Zhou X, Hansmann MA, Davis CC, Suzuki H, Brown CJ, Schütte U, et al. The vaginal bacterial communities of Japanese women resemble those of women in other racial groups. FEMS Immunol Med Microbiol. 2010;58(2): 169-81. https://doi.org/10.1111/j.1574-695X.2009.00618.x.

34. Borgdorff $H$, van der Veer $C$, van Houdt R, Alberts CJ, de Vries HJ, Bruisten $S M$, et al. The association between ethnicity and vaginal microbiota composition in Amsterdam, the Netherlands. PLoS One. 2017;12(7): e0181135. https://doi.org/10.1371/journal.pone.0181135.

35. Moher D, Liberati A, Tetzlaff J, Altman D, The PRISMA group. Preferred Reporting Items for Systematic Reviews and Meta-Analyses: The PRISMA Statement. PLoS Med. 2009;6:e1000097.

36. World Bank. Sub-Saharan Africa | Data. https://data.worldbank.org/region/ sub-saharan-africa. Accessed 10 Jan 2020.

37. Frank DN, Manigart $O$, Leroy $V$, Meda $N$, Valéa D, Zhang $W$, et al. Altered vaginal microbiota are associated with perinatal mother-to-child transmission of HIV in African women from Burkina Faso. J Acquir Immune Defic Syndr. 2012;60(3):299-306. https://doi.org/10.1097/QAl. Ob013e31824e4bdb

38. Gudza-Mugabe M, Havyarimana E, Jaumdally S, Garson KL, Lennard K, Tarupiwa A, et al. HIV infection is associated with preterm delivery independent of vaginal microbiota in pregnant African women. $J$ Infect Dis. 2019;221(7):1194-203. https://doi.org/10.1093/infdis/jiz584.

39. Bisanz JE, Enos MK, PrayGod G, Seney S, Macklaim JM, Chilton S, et al. Microbiota at multiple body sites during pregnancy in a rural tanzanian population and effects of Moringa-supplemented probiotic yogurt. Appl Environ Microbiol. 2015;81(15):4965-75. https://doi.org/10.1128/AEM.00780-15.

40. Brabin L, Roberts SA, Gies S, Nelson A, Diallo S, Stewart CJ, et al. Effects of long-term weekly iron and folic acid supplementation on lower genital tract infection - a double blind, randomised controlled trial in Burkina Faso. BMC Med. 2017;15(1):206. https://doi.org/10.1186/s12916-017-0967-5.

41. McMillan A, Rulisa S, Gloor GB, Macklaim JM, Sumarah M, Reid G. Pilot assessment of probiotics for pregnant women in Rwanda. PLoS One. 2018; 13(6):e0195081. https://doi.org/10.1371/journal.pone.0195081. 
42. Price JT, Vwalika B, Hobbs M, Nelson JAE, Stringer EM, Zou F, et al. Highly diverse anaerobe-predominant vaginal microbiota among HIV-infected pregnant women in Zambia. PLoS One. 2019;14(10):e0223128. https://doi. org/10.1371/journal.pone.0223128.

43. Borgdorff H, Verwijs MC, Wit FWNM, Tsivtsivadze E, Ndayisaba GF, Verhelst R, et al. The impact of hormonal contraception and pregnancy on sexually transmitted infections and on cervicovaginal microbiota in african sex workers. Sex Transm Dis. 2015;42(3):143-52. https://doi.org/10.1097/OLQ. 0000000000000245.

44. Siiteri PK, MacDonald PC. Placental estrogen biosynthesis during human pregnancy. J Clin Endocrinol Metab. 1966;26(7):751-61. https://doi.org/1 0.1210/jcem-26-7-751.

45. O'Hanlon DE, Moench TR, Cone RA. Vaginal pH and microbicidal lactic acid when lactobacilli dominate the microbiota. PLoS One. 2013;8(11):e80074. https://doi.org/10.1371/journal.pone.0080074.

46. Van De Wijgert JHHM, Borgdorff H, Verhelst R, Crucitti T, Francis S, Verstraelen $\mathrm{H}$, et al. The vaginal microbiota: what have we learned after a decade of molecular characterization? 2014. https://doi.org/10.1371/journal. pone.0105998.

47. Freitas AC, Chaban B, Bocking A, Rocco M, Yang S, Hill JE, et al. The vaginal microbiome of pregnant women is less rich and diverse, with lower prevalence of Mollicutes, compared to non-pregnant women. Sci Rep. 2017; 7(1):9212. https://doi.org/10.1038/s41598-017-07790-9.

48. Kroon SJ, Ravel J, Huston WM. Cervicovaginal microbiota, women's health, and reproductive outcomes. Fertil Steril. 2018;110(3):327-36. https://doi. org/10.1016/j.fertnstert.2018.06.036.

49. Walther-António MRS, Jeraldo P, Berg Miller ME, Yeoman CJ, Nelson KE, Wilson BA, et al. Pregnancy's stronghold on the vaginal microbiome. PLoS One. 2014;9(6):e98514. https://doi.org/10.1371/journal.pone.0098514.

50. Kervinen K, Kalliala I, Glazer-Livson S, Virtanen S, Nieminen P, Salonen A Vaginal microbiota in pregnancy: role in induction of labor and seeding the neonate's microbiota? J Biosci. 2019;44(5):1-6. https://doi.org/10.1007/s1203 8-019-9925-z.

51. Tabatabaei N, Eren A, Barreiro L, Yotova V, Dumaine A, Allard C, et al. Vaginal microbiome in early pregnancy and subsequent risk of spontaneous preterm birth: a case-control study. BJOG An Int J Obstet Gynaecol. 2019; 126(3):349-58. https://doi.org/10.1111/1471-0528.15299.

52. Balaka B, Agbèrè A, Dagnra A, Baeta $S$, Kessie K, Assimadi K. Portage génital bactérien au dernier trimestre de la grossesse et infection néonatale précoce. Arch Pediatr. 2005;12(5):514-9. https://doi.org/10.1016/j.arcped.2 005.02.010.

53. Kim JH, Yoo SM, Sohn YH, Jin CH, Yang YS, Hwang IT, et al. Predominant Lactobacillus species types of vaginal microbiota in pregnant Korean women: quantification of the five Lactobacillus species and two anaerobes. J Matern Neonatal Med. 2017;30(19):2329-33. https://doi.org/10.1080/14 767058.2016 .1247799 .

54. Onderdonk AB, Delaney ML, Fichorova RN. The human microbiome during bacterial vaginosis. Clin Microbiol Rev. 2016;29(2):223-38. https://doi.org/1 0.1128/CMR.00075-15.

55. Abdool Karim SS, Baxter C, Passmore JS, McKinnon LR, Williams BL. The genital tract and rectal microbiomes: their role in HIV susceptibility and prevention in women. J Int AIDS Soc. 2019;22(5):e25300. https://doi.org/10.1 002/jia2.25300.

56. Ravel J, Brotman RM. Translating the vaginal microbiome: gaps and challenges. Genome Med. 2016;8(1):35. https://doi.org/10.1186/s13073-016-0291-2.

57. Nguyen DP, Genc M, Vardhana S, Babula O, Onderdonk A, Witkin SS. Ethnic differences of polymorphisms in cytokine and innate immune system genes in pregnant women. Obstet Gynecol. 2004;104(2):293-300. https://doi.org/1 0.1097/01.AOG.0000133486.85400.5e.

58. Ness RB, Haggerty CL, Harger G, Ferrell R. Differential distribution of allelic variants in cytokine genes among African Americans and white Americans. Am J Epidemiol. 2004;160(11):1033-8. https://doi.org/10.1093/aje/kwh325.

59. Ryckman KK, Williams SM, Krohn MA, Simhan HN. Racial differences in cervical cytokine concentrations between pregnant women with and without bacterial vaginosis. J Reprod Immunol. 2008;78(2):166-71. https:// doi.org/10.1016/j.jri.2008.01.003

60. Barton PT, Gerber S, Skupski DW, Witkin SS. Interleukin-1 receptor antagonist gene polymorphism, vaginal Interleukin-1 receptor antagonist concentrations, and vaginal Ureaplasma urealyticum colonization in pregnant women downloaded from. Infect Immun. 2003;71(1):271-4. https://doi.org/10.1128/IAl.71.1.271-274.2003.
61. Genc MR, Vardhana S, Delaney ML, Onderdonk A, Tuomala R, Norwitz E, et al. Relationship between a toll-like receptor-4 gene polymorphism, bacterial vaginosis-related flora and vaginal cytokine responses in pregnant women. Eur J Obstet Gynecol Reprod Biol. 2004;116(2):152-6. https://doi. org/10.1016/j.ejogrb.2004.02.010.

62. Goepfert AR, Varner M, Ward K, Macpherson C, Klebanoff M, Goldenberg RL, et al. Differences in inflammatory cytokine and toll-like receptor genes and bacterial vaginosis in pregnancy. Am J Obstet Gynecol. 2005;193(4):1478-85. https://doi.org/10.1016/j.ajog.2005.03.053.

63. Si J, You HJ, Yu J, Sung J, Ko GP. Prevotella as a hub for vaginal microbiota under the influence of host genetics and their association with obesity. Cell Host Microbe. 2017;21(1):97-105. https://doi.org/10.1016/j.chom.2016.11.010.

64. Murphy K, Mitchell CM. The interplay of host immunity, environment and the risk of bacterial vaginosis and associated reproductive health outcomes. J Infect Dis. 2016;214(suppl 1):S29-35. https://doi.org/10.1093/infdis/jiw140.

65. Koedooder R, Mackens S, Budding A, Fares D, Blockeel C, Laven J, et al. Identification and evaluation of the microbiome in the female and male reproductive tracts. Hum Reprod Update. 2019;25(3):298-325. https://doi. org/10.1093/humupd/dmy048.

66. Chu DM, Seferovic M, Pace RM, Aagaard KM. The microbiome in preterm birth. Best Pract Res Clin Obstet Gynaecol. 2018;52:103-13. https://doi.org/1 0.1016/j.bpobgyn.2018.03.006.

67. Rampersaud R, Planet PJ, Randis TM, Kulkarni R, Aguilar JL, Lehrer Rl, et al. Inerolysin, a cholesterol-dependent cytolysin produced by Lactobacillus iners. J Bacteriol. 2011;193(5):1034-41. https://doi.org/10.1128/JB.00694-10.

68. Machado A, Jefferson KK, Cerca N. Interactions between Lactobacillus crispatus and Bacterial Vaginosis (BV)-Associated Bacterial Species in Initial Attachment and Biofilm Formation. Int J Mol Sci. 2013;14:12004-12. https:// doi.org/10.3390/IJMS140612004.

69. Ghartey JP, Carpenter C, Gialanella P, Rising C, McAndrew TC, Mhatre M et al. Association of bactericidal activity of genital tract secretions with Escherichia coli colonization in pregnancy. Am J Obstet Gynecol. 2012;207: 297.e1-8.

70. Borgdorff H, Armstrong SD, Tytgat HLP, Xia D, Ndayisaba GF, Wastling JM, et al. Unique insights in the cervicovaginal Lactobacillus iners and $L$. crispatus proteomes and their associations with microbiota dysbiosis. PLoS One. 2016;11(3):e0150767. https://doi.org/10.1371/journal.pone.0150767.

71. Petricevic L, Domig KJ, Nierscher FJ, Sandhofer MJ, Fidesser M, Krondorfer I, et al. Characterisation of the vaginal Lactobacillus microbiota associated with preterm delivery. Sci Rep. 2014;4.

72. Kindinger LM, Bennett PR, Lee YS, Marchesi JR, Smith A, Cacciatore S, et al. The interaction between vaginal microbiota, cervical length, and vaginal progesterone treatment for preterm birth risk. Microbiome. 2017;5(1):6. https://doi.org/10.1186/s40168-016-0223-9.

73. UNAIDS. Miles to go closing gaps breaking barriers righting injustices. Geneva; 2018. https://www.unaids.org/sites/default/files/media_asset/milesto-go_en.pdf. Accessed 11 Jan 2020

74. Lewis FMT, Bernstein KT, Aral SO. Vaginal microbiome and its relationship to behavior, sexual health, and sexually transmitted diseases. Obstet Gynecol. 2017;129(4):643-54. https://doi.org/10.1097/AOG.0000000000001932.

75. Atashili J, Poole C, Ndumbe PM, Adimora AA, Smith JS. Bacterial vaginosis and HIV acquisition: a meta-analysis of published studies. AIDS. 2008;22(12): 1493-501. https://doi.org/10.1097/QAD.0b013e3283021a37.

76. Pyles RB, Vincent $\mathrm{KL}$, Baum MM, Elsom B, Miller AL, Maxwell C, et al. Cultivated vaginal microbiomes Alter HIV-1 infection and antiretroviral efficacy in colonized epithelial multilayer cultures. PLoS One. 2014;9(3): e93419. https://doi.org/10.1371/journal.pone.0093419.

77. Cone RA. Vaginal microbiota and sexually transmitted infections that may influence transmission of cell-associated HIV. J Infect Dis. 2014;210(suppl_3): S616-21. https://doi.org/10.1093/infdis/jiu459.

78. Brotman RM, Bradford LL, Conrad M, Gajer P, Ault K, Peralta L, et al. Association between trichomonas vaginalis and vaginal bacterial community composition among reproductive-age women. Sex Transm Dis. 2012;39(10):807-12. https://doi.org/10.1097/OLQ.0b013e3182631c79.

79. UNAIDS. AIDSinfo, people living with HIV receiving ART. 2019. http://a idsinfo.unaids.org/. Accessed 4 Nov 2020.

80. Avert. HIV and AIDS in East and Southern Africa regional overview. 2019. https://www.avert.org/professionals/hiv-around-world/sub-saharan-africa/ overview. Accessed 4 Nov 2020.

81. Linguissi LSG, Sagna T, Soubeiga ST, Gwom LC, Nkenfou CN, Obiri-Yeboah $D$, et al. Prevention of mother-to-child transmission (PMTCT) of HIV: a review 
of the achievements and challenges in Burkina-Faso. HIV/AIDS Res Palliat Care. 2019;11:165-77. https://doi.org/10.2147/HIV.S204661.

82. Organization WH. PMTCT strategic vision 2010-2015: preventing mother-tochild transmission of HIV to reach the UNGASS and millennium development goals: moving towards. 2010. https://apps.who.int/iris/bitstrea m/handle/10665/44268/9789241599030_eng.pdf. Accessed 4 Nov 2020.

83. Bell C, Hough E, Smith A, Greene L. Targeted screening for trichomonas vaginalis in women, a pH-based approach. Int J STD AIDS. 2007;18(6):402-3. https://doi.org/10.1258/095646207781024892.

84. Brotman RM, Klebanoff MA, Nansel TR, Yu KF, Andrews WW, Zhang J, et al. Bacterial vaginosis assessed by gram stain and diminished colonization resistance to incident gonococcal, chlamydial, and Trichomonal genital infection. J Infect Dis. 2010;202(12):1907-15. https://doi.org/10.1086/657320.

85. Mirmonsef $P$, Krass L, Landay A, Spear GT. The role of bacterial vaginosis and trichomonas in HIV transmission across the female genital tract. Curr HIV Res. 2012;10(3):202-10. https://doi.org/10.2174/157016212800618165.

86. Martin DH, Zozaya M, Lillis LM RA, Nsuami MJ, Ferris MJ. Unique Vaginal Microbiota That Includes an Unknown Mycoplasma-Like Organism Is Associated With Trichomonas vaginalis Infection. J Infect Dis. 2013;207: 1922-31. https://doi.org/10.1093/infdis/jit100.

87. Food and Agriculture Organization of the United Nation. State of food insecurity in the world. Rome; 2014.

88. Ruiz L, Moles L, Gueimonde M, Rodriguez JM. Perinatal microbiomes' influence on preterm birth and Preterms' health. J Pediatr Gastroenterol Nutr. 2016;63(6):e193-203. https://doi.org/10.1097/MPG.0000000000001196.

89. Torcia MG. Interplay among vaginal microbiome, immune response and sexually transmitted viral infections. Int J Mol Sci. 2019;20(2). https://doi. org/10.3390/ijms20020266.

90. Anukam KC, Osazuwa E, Osemene GI, Ehigiagbe F, Bruce AW, Reid G. Clinical study comparing probiotic Lactobacillus GR-1 and RC-14 with metronidazole vaginal gel to treat symptomatic bacterial vaginosis. Microbes Infect. 2006;8(12-13):2772-6. https://doi.org/10.1016/j.micinf.2006. 08.008 .

91. Macklaim JM, Clemente JC, Knight R, Gloor GB, Reid G. Changes in vaginal microbiota following antimicrobial and probiotic therapy. Microb Ecol Health Dis. 2015;26. https://doi.org/10.3402/mehd.v26.27799.

92. Taddei CR, Cortez RV, Mattar R, Torloni MR, Daher S. Microbiome in normal and pathological pregnancies: a literature overview. Am J Reprod Immunol. 2018;80(2):e12993. https://doi.org/10.1111/aji.12993.

93. Brown RG, Marchesi JR, Lee YS, Smith A, Lehne B, Kindinger LM, et al. Vaginal dysbiosis increases risk of preterm fetal membrane rupture, neonatal sepsis and is exacerbated by erythromycin. BMC Med. 2018;16(1):9. https:// doi.org/10.1186/s12916-017-0999-x.

94. Peelen MJ, Luef BM, Lamont RF, de Milliano I, Jensen JS, Limpens J, et al. The influence of the vaginal microbiota on preterm birth: a systematic review and recommendations for a minimum dataset for future research. Placenta. 2019;79:30-9. https://doi.org/10.1016/j.placenta.2019.03.011.

95. Solt I. The human microbiome and the great obstetrical syndromes: a new frontier in maternal-fetal medicine. Best Pract Res Clin Obstet Gynaecol. 2015;29(2):165-75. https://doi.org/10.1016/j.bpobgyn.2014.04.024.

96. Parnell $L A$, Briggs $C M$, Mysorekar IU. Maternal microbiomes in preterm birth recent progress and analytical pipelines. Semin Perinatol. 2017;41(7):392400. https://doi.org/10.1053/j.semperi.2017.07.010.

97. Donders G, De Wet HG, Hooft P, Desmyter J. Lactobacilli in Papanicolaou smears, genital infections, and pregnancy. Am J Perinatol. 1993;10(05):35861. https://doi.org/10.1055/s-2007-994761.

98. Juliana NCA, Suiters MJM, Al-Nasiry S, Morré SAPR, AE. The association between vaginal microbiota dysbiosis, bacterial vaginosis and aerobic vaginitis, and adverse pregnancy outcomes of women living in sub-Saharan Africa: A systematic review. Front Public Health. 2020.

99. Hummelen R, Fernandes AD, Macklaim JM, Dickson RJ, Changalucha J, Gloor GB, et al. Deep sequencing of the vaginal microbiota of women with HIV. PLoS One. 2010;5(8):e12078. https://doi.org/10.1371/journal. pone.0012078.

100. Xue Z, Kable ME, Marco ML. Impact of DNA Sequencing and Analysis Methods on 165 rRNA Gene Bacterial Community Analysis of Dairy Products. mSphere. 2018;3.

101. Bukin YS, Galachyants YP, Morozov IV, Bukin SV, Zakharenko AS, Zemskaya TI. The effect of 16 s rRNA region choice on bacterial community metabarcoding results. Sci Data. 2019;6(1):1-14. https://doi.org/10.1038/sda ta.2019.7.
102. Schellenberg J, Links MG, Hill JE, Dumonceaux TJ, Peters GA, Tyler S, et al. Pyrosequencing of the chaperonin-60 universal target as a tool for determining microbial community composition. Appl Environ Microbiol. 2009;75(9):2889-98. https://doi.org/10.1128/AEM.01640-08.

103. Callahan BJ, DiGiulio DB, Aliaga Goltsman DS, Sun CL, Costello EK, Jeganathan $\mathrm{P}$, et al. Replication and refinement of a vaginal microbial signature of preterm birth in two racially distinct cohorts of US women. Proc Natl Acad Sci U S A. 2017;114(37):9966-71. https://doi.org/10.1073/pna S. 1705899114

104. World Health Organization. Global health sector strategy on sexually transmitted infections 2016-2021. Geneva: Towards ending STIs; 2016 https://apps.who.int/iris/bitstream/handle/10665/246296/WHO-RHR-16.09eng.pdf. Accessed 23 Mar 2020

\section{Publisher's Note}

Springer Nature remains neutral with regard to jurisdictional claims in published maps and institutional affiliations.

\section{Ready to submit your research? Choose BMC and benefit from:}

- fast, convenient online submission

- thorough peer review by experienced researchers in your field

- rapid publication on acceptance

- support for research data, including large and complex data types

- gold Open Access which fosters wider collaboration and increased citations

- maximum visibility for your research: over $100 \mathrm{M}$ website views per year

At $\mathrm{BMC}$, research is always in progress.

Learn more biomedcentral.com/submissions 